\title{
IS THE FASHION STORE, PT MATAHARI DEPARTMENT STORE TBK STILL PROFITABLE IN THE ERA OF DIGITAL INNOVATION? For the Period of 2008-2017
}

\author{
Wiwiek Mardawiyah Daryanto ${ }^{1}$, Fransiscus X John Brazer ${ }^{2}$, Jodipati Alif ${ }^{2}$ \\ ${ }^{1}$ Sekolah Tinggi Manajemen IPMI, Jakarta, Indonesia \\ ${ }^{2}$ Sekolah Bisnis dan Manajemen ITB, Bandung, Indonesia
}

Article Information

Received: 16 March 2020

Accepted: 28 April. 2020

Published: 18 May 2020

DOI: $10.33555 /$ ijembm.v7i1.121

Corresponding Author:

Wiwiek Mardawiyah Daryanto Jakarta, Indonesia

Email: wiwiek.daryanto@ipmi.ac.id

ISSN 2338-8854

eISSN 2620-9918

\begin{abstract}
Retail industry in Indonesia has grown rapidly alongside with the current growing of technology. By the ever-growing technology development, the behaviors of Indonesian people are also slightly changes to become more efficient and simple way of buying things. The study sought to observe the performance of PT Matahari Department Store Tbk (MDS) before and after the digital innovation that took place in the early 2010s. The aim of this study was to investigate whether the advent of E-commerce has affected PT MDS's performance. Financial ratio such as profitability and overall measures were used to analyze PT MDS's financial performance. Period taken in this study were in before (2008-2010) and after the appearance of E-Commerce in retail industry (2011-2017). This study found that in 2008-2010 (E-commerce first pilot project) the profitability performance of PT MDS was not in good condition. However, in 2011 or E-Commerce Emergence \& Transition, PT MDS began to improve its financial performance by successfully recording positive trends in all financial ratios except ROE. This has occurred due to the impact of reverse stock and corporate restructuring in 2009. Additionally, an increase in the shareholding of public ownership was also taken in action in 2013 to drive up the price of company's shares and boost the company's ratio. Thus, it can be sum up that PT MDS's financial performance was not affected by the presence of E-commerce, instead it influenced by company's actions. However, with an objective to adapt in this era, PT MDS has launched Matahari.com for targeting other segments and other strategies to keep up the improvements.
\end{abstract}

Keywords: Digitalization, E-Commerce, Financial Performance, Financial Ratio, Retail Industry 


\section{Introduction}

The development of the digital world around the world is very fast and dynamics, this growth is influenced by the growth of internet users in the world. The growth of internet users since it was first discovered in the 1960s and began to soar in 2000 was very fast. The growth of internet users in the world grew from 1 billion users in 2005 to increase to 3.5 billion users in 2017 or grew by 2.5 times in that period (Statista Research, 2018).

In Indonesia alone, there were 500 thousand internet users in 1998, then grew to 143 million users in 2017 or grew by 286 times (Association of Indonesian Internet Service Providers - APJII, 2018). The tremendous growth of internet users is very influential on the life and lifestyle of the Indonesian people, one of which is the emergence of the trend of buying and selling online (e-commerce).

E-commerce itself in Indonesia began in 1996, with the establishment of Dyviacom Intrabumi or D-Net as a pioneer in online transactions, this year the site of Bhinneka.com was first introduced to the people of Indonesia. E-commerce itself continued to grow from 2000 with the emergence of Tokobagus.com, the establishment of Tokopedia.com in 2009, the establishment of Bukalapak.com in 2010, Rakuten in 2011, Zalora in 2011, Elevenia.com in 2014 and JD.ID in 2015. The presence of e-commerce in Indonesia led to changes in the behavior of the Indonesian people in trading activities. This change is a breakthrough in shopping, facilitating the daily activities of the community, opening business opportunities, as well as becoming a new challenge for conventional retail companies. With the trend of shopping online in Indonesia, which began to boom in 2011, the people who originally visited the shop to shop, switched to using online shopping facilities because of the convenience offered, both in buying daily necessities and shopping for fashion products needed.

PT. Matahari Department Store Tbk. or better known as Matahari Dept. Store (MDS) is one of the conventional retail fashion companies that have been known for a long time by the people of Indonesia. Since its establishment in 1982, Matahari Dept. Store has a total of 155 outlets spread across 74 major cities throughout Indonesia. As one of the oldest and largest fashion retail stores in Indonesia which is still operating today, Matahari Dept. Store must face the development of the digital era and compete with new arrivals (fashion retail stores) both offline and online (ecommerce) based.

As a public company, Matahari Department Store strives to generate profits and maintain the company's performance every year to maintain the sustainability of the company, continue to grow, maintain investor confidence and provide welfare to all its stakeholders. With the advent of the challenges of the digital era and the booming of e-commerce since 2010, does PT. Matahari Department Store Tbk. still profitable after the boom in e-commerce? To answer this question, this study refers to PT Matahari Department Store's performance analysis before the ECommerce boom in 2008-2010 and at the beginning of the booming E-commerce from 2011 to 2017.

The study sought to observe the performance of PT Matahari Department Store tbk in the period of before and after the digital innovation took place in the early 2010s. The problem of whether the digital innovation of E-comerce had affected the performance of PT Matahari Department Store tbk was the main observation of the study. Financial statement analysis (financial ratio) tool was used to assess the performance and level of profitability of a company. To measure the profitability and performance of a company, financial 
statement analysis is divided into 5 parts ratios, namely: overall performance measure, profitability measure, and tests of dividend policy (Anthony et al, 2012). However, in this study the ratio used to measure profitability and company performance was 2 parts ratio, namely overall performance measure and profitability measure.

This study is organized into seven sections. Section one captures the introduction, section two highlight the history of Indonesia's conventional fashion retail industry, section three highlights the literature review about previous research, section four discuss the methodology, section five discuss the result and analysis, section six discuss the highlights the limitation, and section seven captures the conclusion and recommendation.

\section{Conventional Fashion Retail Store in Indonesia}

Retail companies is a company that conducts trading activities involving the sale of goods or services to end consumers to be used for something with personal purposes (Kotler, 2000). While for conventional fashion retail store itself is a company that conducts trade activities involving the sale of fashion and accessories type products that have physical stores that can be visited by end consumers (non-corporate).

The fashion retail company itself has started to exist in Indonesia since the 1960s with the establishment of the first retail fashion in Indonesia called Sarinah, followed by the emergence of Pasaraya in 1972, Ramayana in 1978, followed by the presence of Matahari Department Store, Golden Truly. In the 1990s followed by the emergence of SOHO, SEIBU, METRO and other retail fashion to date. The 1990s 2000 s were the golden year for conventional fashion retail store players in
Indonesia, the massively growing new outlets throughout Indonesia, is one indicator of the growth of the industry conventional retail stores in the country. The challenges and new competition for conventional fashion retail in Indonesia began in 2010, where online fashion applications and marketplaces began to emerge and bring major changes to this industry. This technological progress or what we call disruptive innovation makes the business competition map in the industry change and creates new competitors that are different from existing players.

The conventional fashion retail company that originally competed with fellow conventional retail store players had to face new competitors with online based. Changes in the shopping style of the Indonesian people have an influence on the sales of conventional retail store players. Consumers are more fonding of buying fashion products online by using only their cellphones or gadgets without having to bother going to the store. This disruptive innovation forces conventional players to strive to adapt in order to remain profitable and sustainable in the digital era.

\section{Previous Research on Financial Performance}

Financial ratio is a good evaluation method to measure the company performances (Megaladevi, 2015). There have been a large number of empirical studies on financial ratio on different industries around the world (Webb, 2003; Halkos and Salamouris, 2004; Tarawneh, 2006; Daryanto, 2018). According to Tarawneh (2006), the financial ratio analysis (FRA) has been applied in Banking industry to examine, evaluate, and ranked based on their performance. Based on the study in Oman Commercial Banks, financial performance has relationship with asset management, size and operational efficiency. For instance, oil business 
requires high capital, high technology, high risks, long-term commitment, but may be high returns (Daryanto, 2018). The company are encouraged to maintain their profitability by increasing its activity ratios (Daryanto, 2018).

Company usually uses this method to compare their performance with other competitors. However, there are limited resources which evaluate the financial performance of Estate Palm Oil Enterprises in Indonesia (Daryanto, 2017). There are two methods to measure the financial performances which are accounting and market measurement. There are many researchers who prefer to use accounting measurement rather than market measurement and some of them adopt both methods. There are few differences between accounting and market measurement method. In accounting, company use the historical aspects to measure their financial performance and it contain a bias which lead to managerial manipulation. On the other hand, market measurement method is straight forward, focus on performance and represent the ability of a company to generate future income.

In the journal entitled "Analysis of Financial Reports to Assess Financial Performance of PT. Matahari Department Store, which is listed on the $2012-2014$ Indonesia Stock Exchange "(Putri, 2015) explained that PT. Matahari Department Store is included as a non-liquid and nonsolvable company. This analysis is seen using the related financial ratio. Another writing related to this, entitled "Financial Performance Analysis of PT. Matahari Department Store Tbk Based on the Liquidity, Solvability, Profitability, and Activity Ratios in 2010 - 2014 "(Monika, 2016) explains that the profitability of the company is getting better every year, and for the activity ratio, this company is also considered effective in using resources owned compared to other companies with similar industries. To be a comparison with the previous research, this paper will be explained about the financial performance of PT. Matahari Department Store in 2008 - 2017 and its relation to the emergence of e-commerce in Indonesia as a form of innovation digital in retail industry. Comparison that appears is writing with a longer year will describe the condition of this company before and after the emergence of e-commerce, and how much influence from the emergence of ecommerce on profitability and performance results from PT. Matahari Department Store.

\section{Methodology}

This study adapt the secondary analysis in quantitative method. It compared the performance and profitability of PT Matahari Department Store Tbk. in 20082010, in the period before the E-Commerce boom with the company's performance and profitability in the 2011-2017 periods at the beginning of the booming e-commerce to date. This study will therefore address the following research questions, as follows:

1) Did financial performance before the digital innovation significantly differ with that of the post digital innovation?

2) What were the company's strategies to combat the advent of digital innovation? 
Referring to the division of the period, here is the timeline for the emergence of ecommerce in Indonesia:
Timeline of growth E-Commerce and PT Matahari Department Store Tbk. in Indonesia is depicted in Figure 1.

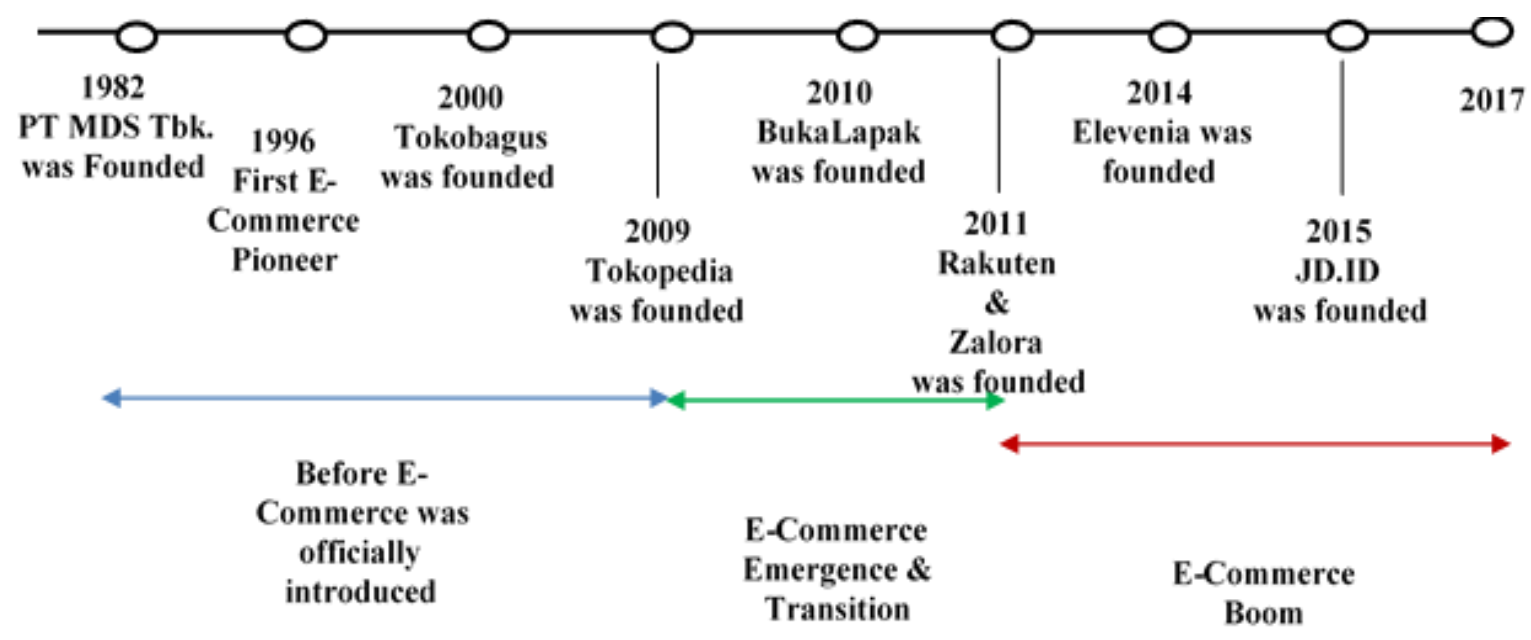

Figure 1. Timeline of growth E-Commerce and PT Matahari Department Store Tbk. in Indonesia (Author Analysis, 2018)

The period of this study is divided on four parts of timeline, as follows:

1) 1982-2009 : Period before E-Commerce officially launched (trial)

2) 2009-2011: Period of appearance of E-Commerce massively

3) 2011 : First period of E-Commerce boom

4) 2011-2017 : E-Commerce already become habitual and Indonesian first choice

Referring to the timeline above, research carried out in the period 2008-2010 (before official e-commerce was present in Indonesia) as the reference data and in the period 2011-2017 (e-commerce began massive emerging and booming) as comparable data on performance and profitability of PT Matahari Department Store Tbk.
The tools used in analyzing the performance and profitability of the company are divided into two (2) parts ratios (Anthony et al, 2012), namely:

\subsection{Overall Performance Measure}

This ratio section is the ratio used to measure company performance in aggregate. This section ratio is divided into 4 ratios, namely:

1) Price/Earnings Ratio

The price/earnings ratio is the ratio of a company's stock price to the company's earnings per share. The ratio is used in valuing companies.

The formula for this ratio:

$$
\frac{\text { Market Price Per Share }}{\text { Net Income Per Share }}
$$

2) Return on Asset

The return on assets shows the percentage of how profitable a company's assets are in generating revenue. 
The formula for this ratio:

$$
\frac{\text { Net Income }+ \text { Interest }(1-\text { Tax Rate })}{\text { Total Assets }}
$$

3) Return on Invested Capital

Return on invested capital, is a ratio used in finance, valuation and accounting, as a measure of the profitability and valuecreating potential of companies after taking into account the amount of initial capital invested.

The formula for this ratio:

$\frac{\text { Net Income }+ \text { Interest }(1-\text { Tax Rate })}{\text { Long Term Liabilities }+ \text { Shareholder's Equity }}$

4) Return on Shareholder's Equity

Return on equity is an important ratio for investors to consider its profits. ROE measures how efficiently a company can use the money from shareholders to generate profits and grow the company (Anthony, 2011). In other words, the return on equity ratio shows how much profit each dollar of common stockholders' equity generates.

The formula for this ratio:

\section{$\frac{\text { Net Income }}{\text { Shareholder's Equity }}$}

\subsection{Profitability Measure}

Profitability measure is a class of financial metrics that are used to assess a business's ability to generate earnings relative to its associated expenses. This ratio section is divide to four (4) ratios, namely:

\section{1) Gross Margin Percentage}

Gross margin is a company's total gross margin divided by its net sales revenue to measure the compare the company gross margin to its net sales revenue.
The formula for this ratio:

$$
\frac{\text { Gross Margin }}{\text { Net Sales Revenue }}
$$

\section{2) Profit Margin}

Profit margin is one of the commonly used profitability ratios to gauge profitability of a business activity. It represents how much percentage of sales has turned into profits.

The formula for this ratio:

$$
\frac{\text { Net Income }}{\text { Net Sales Revenue }}
$$

\section{3) Earnings Per Share}

Earnings per share (EPS) is the portion of a company's profit allocated to each share of common stock.

The formula for this ratio:

$$
\frac{\text { Net Income }}{\text { Number of Shares Outstanding }}
$$

\section{4) Cash Realization}

Cash realization is the ratio to measure the ability of the company to generated/ realized real cash from its total net income.

The formula for this ratio:

\section{Cash Generated By Operations}

Net Income 


\section{Results and Discussion}

\subsection{Overall Performance Measure}

Table 1 shows the financial ratios from 2008 to 2017.

Table 1. Financial Ratios of Overall Performance 2008-2017

\begin{tabular}{|c|c|c|c|c|c|c|c|c|c|c|c|c|}
\hline \multirow{2}{*}{ No } & \multirow{2}{*}{ Ratio } & \multirow{2}{*}{ Formula } & \multicolumn{10}{|c|}{ YEAR } \\
\hline & & & 2008 & 2009 & 2010 & 2011 & 2012 & 2013 & 2014 & 2015 & 2016 & 2017 \\
\hline \multicolumn{13}{|c|}{ Performance Result } \\
\hline & Price/Earnings Ratio & $\begin{array}{l}\text { Market price per share } \\
\text { Net income per share }\end{array}$ & $-16.78 x$ & $-58.33 x$ & $121.42 X$ & $15 x$ & $10.22 \mathrm{x}$ & $27 X$ & $30.96 \mathrm{X}$ & $28.84 X$ & $20.56 \mathrm{X}$ & $15.3 \mathrm{X}$ \\
\hline & Return On Asset & $\frac{\text { Net income + Interest }(1-\text { Tax rate })}{\text { Total asssets }}$ & $-6.2 \%$ & $-1.2 \%$ & $17.5 \%$ & $19.0 \%$ & $26.0 \%$ & $39.2 \%$ & $41.5 \%$ & $45.8 \%$ & $41.6 \%$ & $35.1 \%$ \\
\hline & Return On Invested Capital & $\frac{\text { Net income + Interest (1 - Tax rate) }}{\text { Long-term liabilities + Shareholders' equity }}$ & $-6.9 \%$ & $-5.2 \%$ & $-2.6 \%$ & $121.6 \%$ & $146.1 \%$ & $133.5 \%$ & $182.5 \%$ & $129.6 \%$ & $90.1 \%$ & $68.2 \%$ \\
\hline & Return On Shareholder's Equity & $\frac{\text { Net income }}{\text { Shareholders' equity }}$ & $-8.5 \%$ & $-7.7 \%$ & $58.1 \%$ & $-17.2 \%$ & $-39.9 \%$ & $-147.2 \%$ & $799.1 \%$ & $161.0 \%$ & $108.9 \%$ & $81.9 \%$ \\
\hline
\end{tabular}

\section{Legend :}

\begin{tabular}{|l|l|}
\hline & E-Commerce First Pilot Project (Before E-Commerce) \\
\hline & E-Commerce Emergence \& Transition \\
E-Commerce Boom And Adoption
\end{tabular}

(Source: Author Analysis, 2018)

\subsubsection{Price/Earnings Ratio}

Table 2 and figure 2 shows the calculation of Price Earning Ratio (PER) and Growth.

Table 2. Price Earning Ratio (PER) and Growth Calculations

\begin{tabular}{|c|c|c|}
\hline Year & Ratio & Growth \\
\hline $\mathbf{2 0 0 8}$ & -16.8 X & 0 \\
\hline $\mathbf{2 0 0 9}$ & -58 X & $-247 \%$ \\
\hline $\mathbf{2 0 1 0}$ & 121 X & $308 \%$ \\
\hline $\mathbf{2 0 1 1}$ & 15 X & $88 \%$ \\
\hline $\mathbf{2 0 1 2}$ & 10 X & $32 \%$ \\
\hline $\mathbf{2 0 1 3}$ & 27 X & $-164 \%$ \\
\hline $\mathbf{2 0 1 4}$ & 30.9 X & $-15 \%$ \\
\hline $\mathbf{2 0 1 5}$ & 28.8 X & $7 \%$ \\
\hline $\mathbf{2 0 1 6}$ & 20.5 X & $29 \%$ \\
\hline $\mathbf{2 0 1 7}$ & 15.3 X & $26 \%$ \\
\hline
\end{tabular}

Source: Author Analysis, 2018 


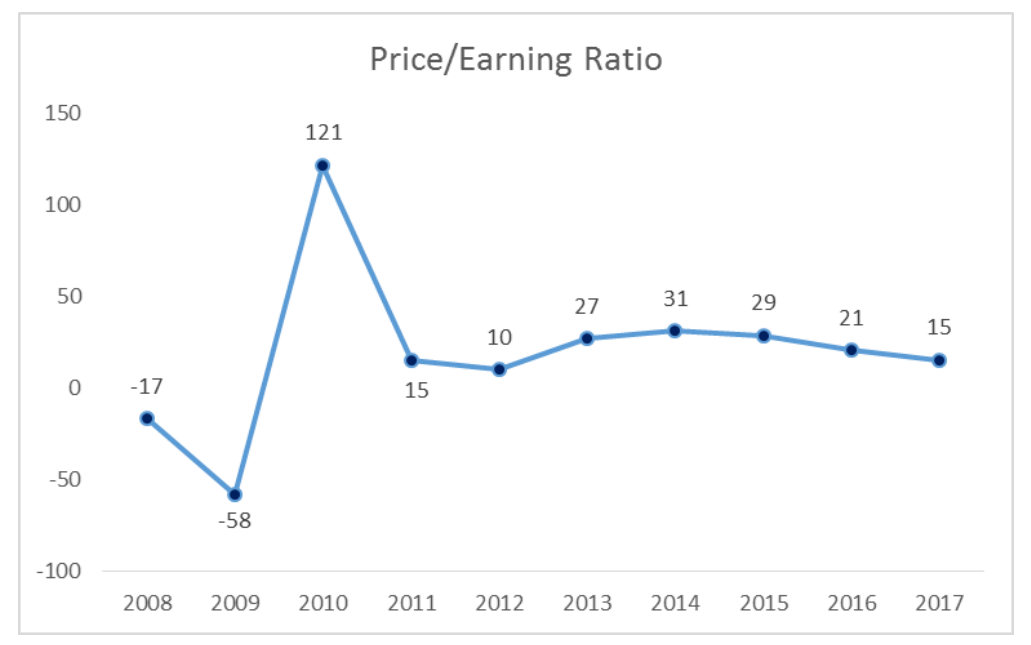

Figure 2. Graph of PER Calculation

(Author, 2018)

PT MDS market price trend:

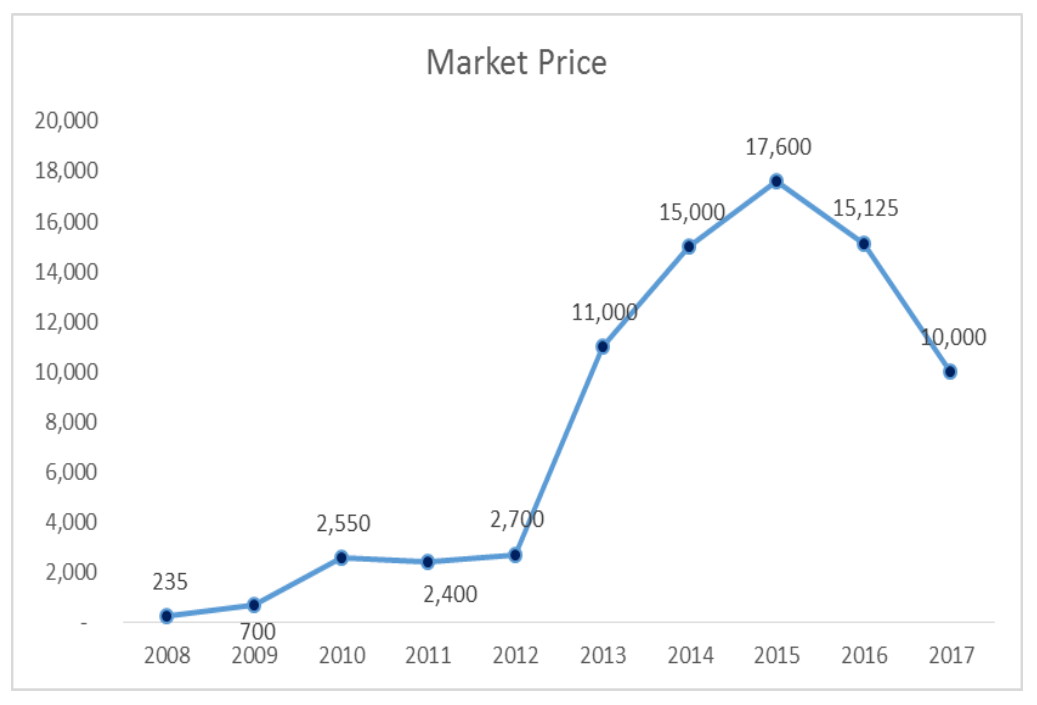

Figure 3. PT MDS Market Price Trend (Author Analysis, 2018)

Figure 3 shows the important events:

A. 2009-2010 : Stock Reverse $1: 5$, Corporate restructurization.

B. 2013 : PT Asia Color Company Ltd, as owner of $98.15 \%$ stock, sell $66 \%$ of their stock publicly $45.7 \%$ to PT Multipolar Tbk around $20.48 \%$. The increasing of public owner of this company stock, push increasing of stock price of PT. MDS.
Based on Table 2 and Figure 2, the Price/Earnings Ratio of PT Matahari Department Store Tbk. Resulting this analysis:

a. Red Period (e-commerce first pilot project)

In 2008, PT MDS suffered a loss resulting in a negative PER. In 2009, PT MDS still suffered a greater loss than in 2008 resulting in even greater PER negative. 2009-2010, PT MDS had succeeded in 
generating profits, the increase in PT MDS PER to 121 times occurred because PT MDS conducted a stock reverse to increase the company's stock price and cut the number of shares outstanding.

\section{b. Blue Period (E-Commerce Emergence and Transition)}

In 2011, PT MDS has adapted to the new stock price since conducting a stock reverse in 2009-2010. PT MDS managed to generate a bigger profit than in 2010 . This caused the PT MDS PER to decline from 2010 where the smaller the PER the better earnings per share produced by the company.

\section{c. Green Period (E-Commerce Boom and Adoption)}

In 2012 PT MDS succeeded in generating a greater profit than in 2011, this resulted in the company's PER improving compared to 2011, the company's PER declined again in 2013-2014 due to the increase in the company's stock price during this period, this was due to PT Asia Color Company Ltd., as the owner of $98 \%$ shares of PT MDS, sold its share ownership to the public for more than $45 \%$, the significant increase in PT MDS's share price was not balanced with the increase in company profits. The company corrected its PER in the 2015-2017 period, this happened because in that year, the company's stock price experienced a correction and a decline in prices.

\subsubsection{Return on Asset (RoA)}

Table 3 and figure 4 below shows the calculation of Return on Asset (RoA).

Table 3. ROA Calculations

\begin{tabular}{|c|c|c|}
\multicolumn{3}{|c}{ ROA } \\
\hline $\mathbf{2 0 a r}$ & Ratio & Growth \\
\hline $\mathbf{2 0 0 9}$ & $-6.2 \%$ & 0 \\
\hline $\mathbf{2 0 1 0}$ & $-1.2 \%$ & $81 \%$ \\
\hline $\mathbf{2 0 1 1}$ & $17.5 \%$ & $1557 \%$ \\
\hline $\mathbf{2 0 1 2}$ & $26.0 \%$ & $37 \%$ \\
\hline $\mathbf{2 0 1 3}$ & $39.2 \%$ & $51 \%$ \\
\hline $\mathbf{2 0 1 4}$ & $41.5 \%$ & $6 \%$ \\
\hline $\mathbf{2 0 1 5}$ & $45.8 \%$ & $10 \%$ \\
\hline $\mathbf{2 0 1 6}$ & $41.6 \%$ & $-9 \%$ \\
\hline $\mathbf{2 0 1 7}$ & $35.1 \%$ & $-15 \%$ \\
\hline
\end{tabular}

Source: Author Analysis, 2018 


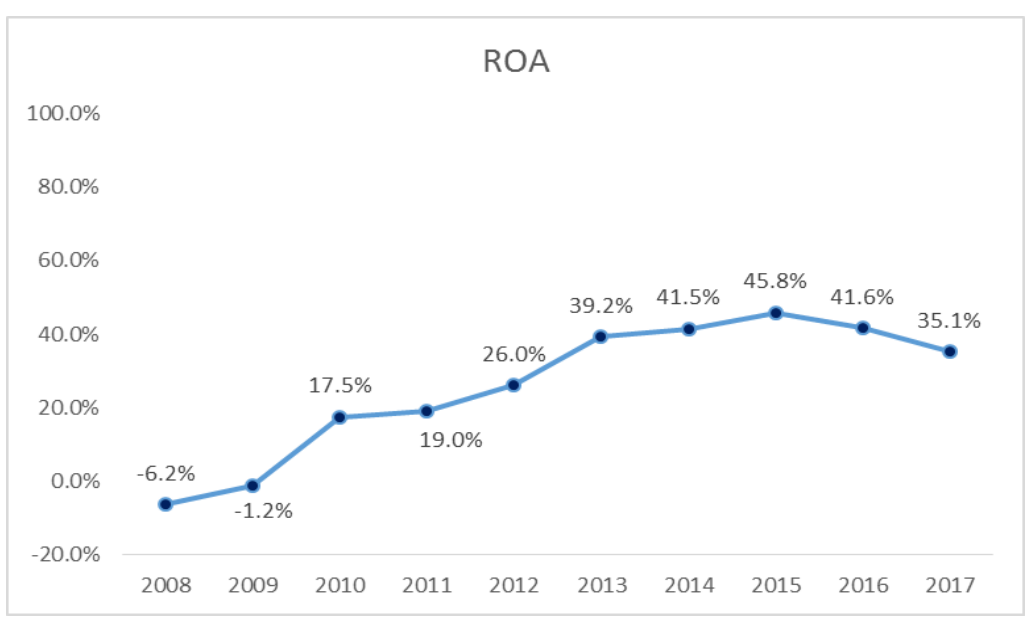

Figure 4. Graph of ROA Calculation (Author Analysis, 2018)

Based on Table 3 and Figure 4 indicate ROA in year of 2008 to 2017 of PT Matahari Department Store Tbk. Resulting this analysis:

a. Red Period (e-commerce first pilot project)

In the 2008-2010 periods, PT MDS managed to record an increase in the ROA trend. In 2008-2009, even though it generated an upward trend, PT MDS produced negative ROA because the company suffered losses in that period. In 2010, corporate restructuring encouraged positive growth at PT MDS. b. Green Period (E-Commerce Boom and Adoption)

In 2012 - 2015 PT MDS succeeded in generating an increase in ROA trend. This is due to the increase in the company's net income. In 2016-2017, company ROA showed a downward trend due to a decrease in the company's net income which was inversely proportional to the increase in the total assets of the company.

\subsubsection{Return on Invested Capital (RoIC)}

Table 4 and figure 5 shows the calculation of Return on Invested Capital (RoIC).

Table 4. RoIC Calculations

\begin{tabular}{|c|c|c|}
\hline Year & Ratio & Growth \\
\hline $\mathbf{2 0 0 8}$ & $-6.9 \%$ & 0 \\
\hline $\mathbf{2 0 0 9}$ & $-5.2 \%$ & $25 \%$ \\
\hline $\mathbf{2 0 1 0}$ & $-2.6 \%$ & $50 \%$ \\
\hline $\mathbf{2 0 1 1}$ & $121.6 \%$ & $4849 \%$ \\
\hline $\mathbf{2 0 1 2}$ & $146.1 \%$ & $20 \%$ \\
\hline $\mathbf{2 0 1 3}$ & $133.5 \%$ & $-9 \%$ \\
\hline $\mathbf{2 0 1 4}$ & $182.5 \%$ & $37 \%$ \\
\hline $\mathbf{2 0 1 5}$ & $129.6 \%$ & $-29 \%$ \\
\hline $\mathbf{2 0 1 6}$ & $90.1 \%$ & $-30 \%$ \\
\hline $\mathbf{2 0 1 7}$ & $68.2 \%$ & $-24 \%$ \\
\hline
\end{tabular}

Source: Author Analysis, 2018 


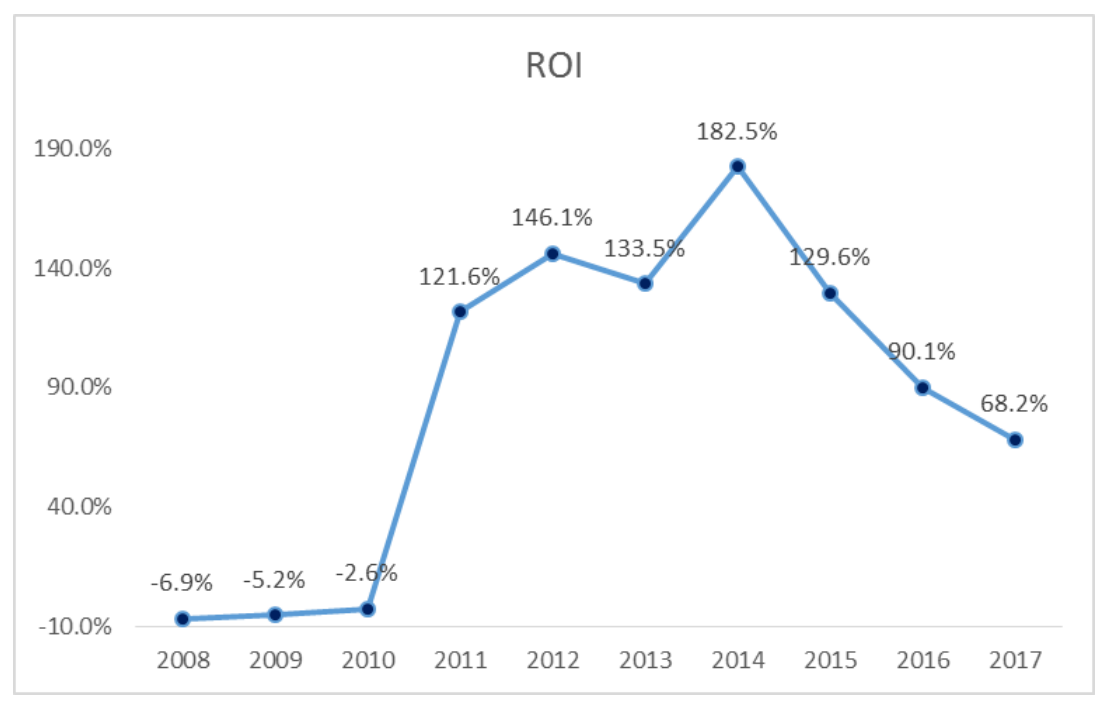

Figure 5. Graph of RoIC Calculation (Author Analysis, 2018)

Based on Table 4 and Figure 5 indicate RoIC in year of 2008 to 2017 of PT Matahari Department Store Tbk. Resulting this analysis:

\section{a. Red Period (e-commerce first pilot project)}

In the 2008-2010 periods, PT MDS managed to record an increase in the ROI trend. But in that year, PT MDS produced a negative ROI, this was caused by the company still experiencing losses.

\section{b. Blue Period (E-Commerce Emer-gence and Transition)}

In 2011, PT MDS generated a positive ROI and experienced a very significant increase. This happened because since 2010, PT MDS restructured its company and there was a change in ownership of shares and the difference between the transfer price and book value related to the restructuring of entities under common control was not recorded as an account "Difference in Value of Restructu-ring Transactions of Entities under Common Control" and presented as part of equity in the statement of financial position. This listing caused the company's total equity to be negative.

\section{c. Green Period (E-Commerce Boom and Adoption)}

In 2012 PT MDS succeeded in producing an increasing ROI trend. This was due to the increase in the company's net income and the company's total equity due to the impact of corporate restruc-turing in 2010. In 2013, the company's ROI showed a downward trend. This happened because the company still recorded a minus equity, but minus equity was reduced due to the addition of retained earnings. In 2014, the company's ROI rose significantly from the previous year, this was because the company reduced its long-term debt by paying its long-term debt with a considerable value (Rp. 1.15 trillion) with an equity minus condition. In the period of 2015-2017, the company's ROI experienced a downward trend because companies began to improve their equity with the addition of retained earnings. In this period, the company's equity has shown a positive number. 


\subsubsection{Return on Shareholder's Equity}

Table 5 and figure 6 shows the calculation of Return on Shareholder's Equity calculation.

Table 5. RoE Calculations

\begin{tabular}{|c|c|c|}
\hline Year & Ratio & Growth \\
\hline $\mathbf{2 0 0 8}$ & $-8.5 \%$ & 0 \\
\hline $\mathbf{2 0 0 9}$ & $-7.7 \%$ & $10 \%$ \\
\hline $\mathbf{2 0 1 0}$ & $58.1 \%$ & $859 \%$ \\
\hline $\mathbf{2 0 1 1}$ & $-17.2 \%$ & $-130 \%$ \\
\hline $\mathbf{2 0 1 2}$ & $-39.9 \%$ & $-132 \%$ \\
\hline $\mathbf{2 0 1 3}$ & $-147.2 \%$ & $-269 \%$ \\
\hline $\mathbf{2 0 1 4}$ & $799.1 \%$ & $643 \%$ \\
\hline $\mathbf{2 0 1 5}$ & $161.0 \%$ & $-80 \%$ \\
\hline $\mathbf{2 0 1 6}$ & $108.9 \%$ & $-32 \%$ \\
\hline $\mathbf{2 0 1 7}$ & $81.9 \%$ & $-25 \%$ \\
\hline
\end{tabular}

Source: Author Analysis, 2018

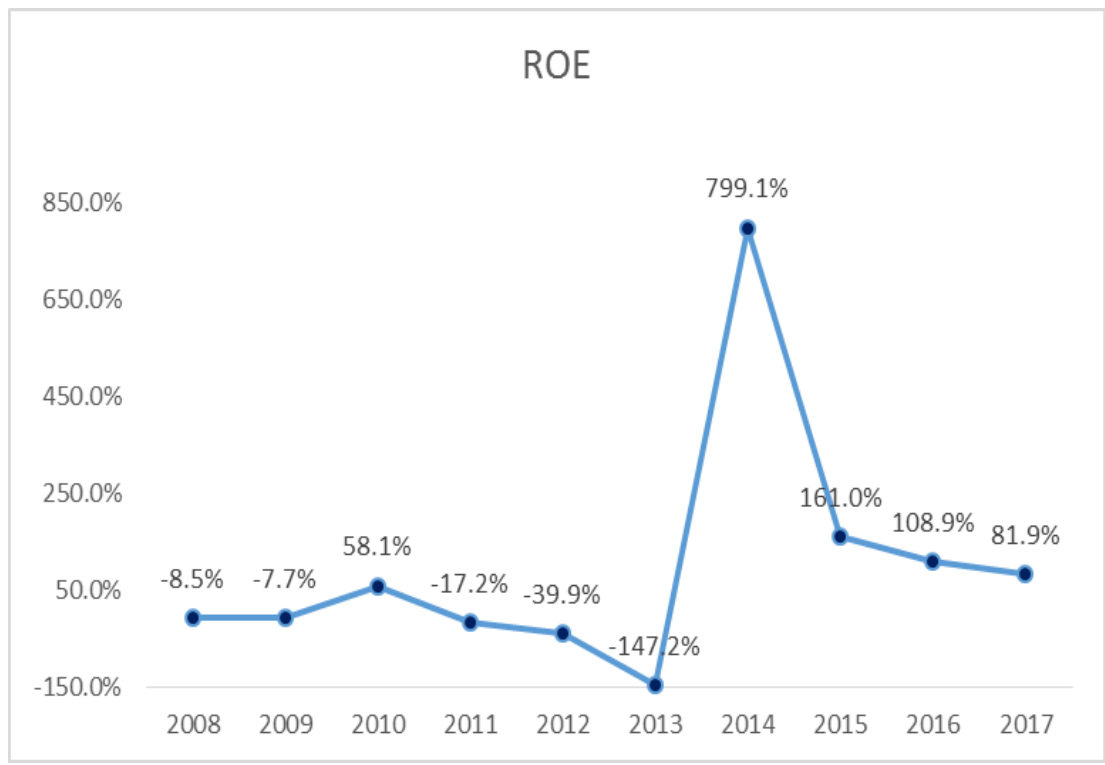

Figure 6. Graph of RoE Calculation (Author Analysis, 2018)

Based on Table 5 and Figure 6 indicate RoE in year of 2008 to 2017 of PT Matahari Department Store Tbk. Resulting this analysis:

a. Red Period (e-commerce first pilot project)
In the 2008-2009 periods, PT MDS recorded a negative ROE, even though ROE was successfully repaired in 2009. This happened because the company suffered losses in 2008-2009, but the loss narrowed in 2009. In 2010, the company managed to record ROE positive. This 
happened because in 2010 , the company managed to record profits.

\section{b. Blue Period (E-Commerce Emergen- ce and Transition)}

In 2011, PT MDS produced negative ROE. This happened as an impact of corporate restructuring. PT MDS's restructuring occurs because there is a change in ownership of shares and the difference between the transfer price and book value related to the restructuring of entities under common control is not goodwill but is recorded as "Difference in Value of Restructuring Transactions of Entities under Common Control" and presented as part of equity in the statement of financial position. This listing caused the company's total equity to be negative.

\section{c. Green Period (E-Commerce Boom and Adoption)}

In 2012 PT MDS succeeded in generating an increase in the ROE trend. This was due to the increase in the company's net income and the company's total equity due to the impact of corporate restructuring in 2010. In 2013, the company's ROE showed a downward trend. This happened because the company still recorded a minus equity, but minus equity was reduced due to the addition of retained earnings. In 2014, the company's ROE rose significantly from the previous year, this happened because the company managed to reduce the minus record on equity by adding retained earnings so that the company's equity was positive but with small numbers. In the period of 2015-2017, the company's ROE experienced a downward trend because the company began to improve its equity by adding substantial retained earnings. In this period, the company's equity has shown a positive number and has a positive trend of increasing the number of equity.

\subsection{Profitability Measure}

Table 6 shows the calculation of financial ratios from 2008 to 2017.

Table 6. Financial Ratios of Overall Performance 2008-2017

\begin{tabular}{|c|c|c|c|c|c|c|c|c|c|c|c|c|}
\hline \multirow{2}{*}{ No } & \multirow{2}{*}{ Ratio } & \multirow{2}{*}{ Formula } & \multicolumn{10}{|c|}{ YEAR } \\
\hline & & & 2008 & 2009 & 2010 & 2011 & 2012 & 2013 & 2014 & 2015 & 2016 & 2017 \\
\hline \multicolumn{13}{|c|}{ Profitability Measures } \\
\hline & Gross Margin Percentage & $\frac{\text { Cross margin }}{\text { Net sales revenues }}$ & $35 \%$ & $61.8 \%$ & $64.4 \%$ & $66.1 \%$ & $66.0 \%$ & $64.6 \%$ & $63.7 \%$ & $63.0 \%$ & $62.8 \%$ & $62.5 \%$ \\
\hline & Profit Margin & $\frac{\text { Net income }}{\text { Net sales revenues }}$ & $-32.5 \%$ & $-47.8 \%$ & $23.7 \%$ & $9.9 \%$ & $13.7 \%$ & $17.0 \%$ & $17.9 \%$ & $19.8 \%$ & $20.4 \%$ & $19.0 \%$ \\
\hline & Earning Per Share & $\frac{\text { Net income }}{\text { No. shares outstanding }}$ & $-\operatorname{Rp} 14.0$ & -Rp12.0 & Rp21.0 & Rp160.0 & Rp264.0 & Rp394.2 & Rp486.4 & Rp610.3 & Rp692.2 & Rp653.6 \\
\hline & Cash Realization & $\frac{\text { Cash generated by operations }}{\text { Net income }}$ & $-2.26 \mathrm{x}$ & -34.76 & $1.71 x$ & $3.28 x$ & $2.45 x$ & $1.84 x$ & $1.57 x$ & $1.52 x$ & $1.53 x$ & $1.37 x$ \\
\hline
\end{tabular}

\section{Legend :}

\begin{tabular}{|l|l|}
\hline & E-Commerce First Pilot Project (Before E-Commerce) \\
\cline { 1 - 2 } & E-Commerce Emergence \& Transition \\
\cline { 1 - 2 } & E-Commerce Boom And Adoption
\end{tabular}

(Source: Author Analysis, 2018) 


\subsubsection{Gross Margin Percentage}

Table 7 and figure 7 shows the calculation of Gross Margin Percentage.

Table 7. Gross Margin Calculations

\begin{tabular}{|c|c|c|}
\hline \multicolumn{3}{|c|}{ Gross Margin Percentage } \\
\hline Year & Ratio & Growth \\
\hline $\mathbf{2 0 0 8}$ & $34.6 \%$ & 0 \\
\hline $\mathbf{2 0 0 9}$ & $61.8 \%$ & $79 \%$ \\
\hline $\mathbf{2 0 1 0}$ & $64.4 \%$ & $4 \%$ \\
\hline $\mathbf{2 0 1 1}$ & $66.1 \%$ & $3 \%$ \\
\hline $\mathbf{2 0 1 2}$ & $66.0 \%$ & $-0.1 \%$ \\
\hline $\mathbf{2 0 1 3}$ & $64.6 \%$ & $-2 \%$ \\
\hline $\mathbf{2 0 1 4}$ & $63.7 \%$ & $-1 \%$ \\
\hline $\mathbf{2 0 1 5}$ & $63.0 \%$ & $-1 \%$ \\
\hline $\mathbf{2 0 1 6}$ & $62.8 \%$ & $-0.3 \%$ \\
\hline $\mathbf{2 0 1 7}$ & $62.5 \%$ & $-0.5 \%$ \\
\hline
\end{tabular}

Source: Author Analysis, 2018

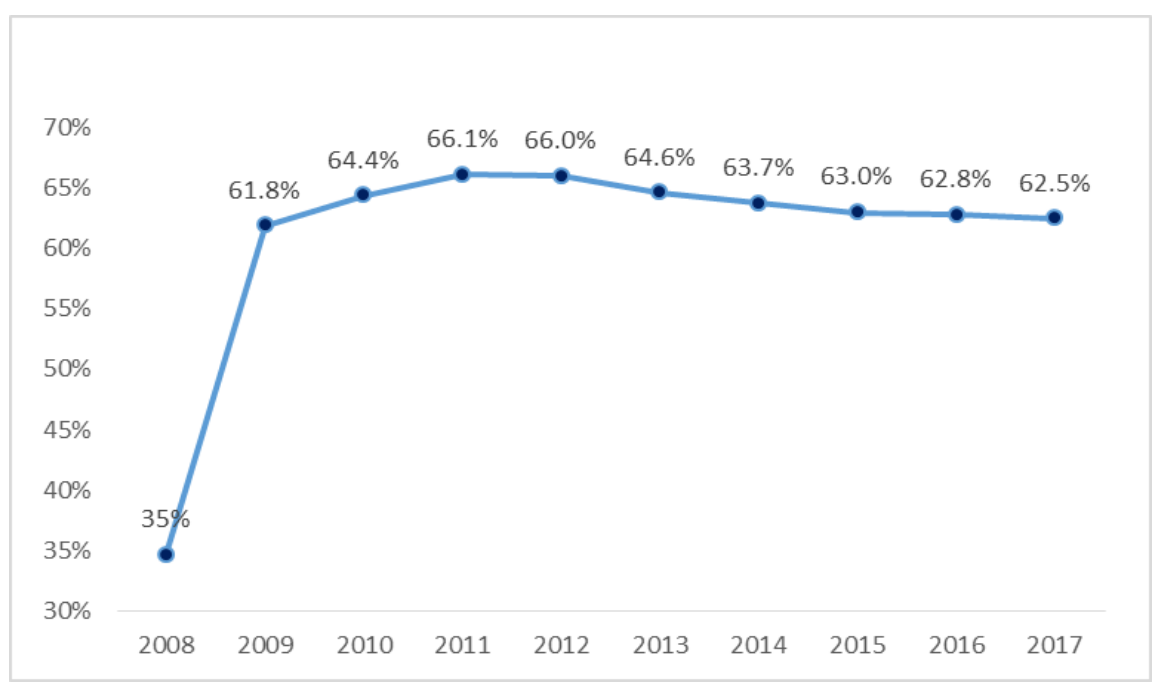

Figure 7. Graph of Gross Margin Calculation (Author Analysis, 2018)

Based on Table 7 and Figure 7 indicate Gross Margin in year of 2008 to 2017 of PT Matahari Department Store Tbk. Resulting this analysis:

a. Red Period (e-commerce first pilot project)

In 2008, PT. MDS recorded a Gross Margin Percentage of $34.6 \%$. This happened because PT. MDS has a small Gross Profit. In 2009 \& 2010 there was an increase that occurred due to an increase in the two existing variables, namely an increase in Gross Profit and Net Sales Revenue from this company.

b. Blue Period (E-Commerce Emergence and Transition)

In 2011, Gross Margin Percentage increased by $3 \%$. This happened because of an increase in the total sales owned by 
PT. MDS in their performance during 2011.

c. Green Period (E-Commerce Boom and Adoption)

During this period, Gross Margin Percentage looks stable but tends to decline every year. This is because the ratio of the value of Gross Profit and Net Sales Revenue has a difference, that resulting in a value of Gross Margin Percentage tends to decrease.

\subsubsection{Profit Margin}

Table 8 and figure 8 shows the calculation of Profit Margin.

Table 8. Profit Margin Calculations

\begin{tabular}{|c|c|c|}
\hline Year & Ratio & Growth \\
\hline $\mathbf{2 0 0 8}$ & $-32.5 \%$ & 0 \\
\hline $\mathbf{2 0 0 9}$ & $-47.8 \%$ & $-47 \%$ \\
\hline $\mathbf{2 0 1 0}$ & $23.7 \%$ & $150 \%$ \\
\hline $\mathbf{2 0 1 1}$ & $9.9 \%$ & $-2 \%$ \\
\hline $\mathbf{2 0 1 2}$ & $13.7 \%$ & $39 \%$ \\
\hline $\mathbf{2 0 1 3}$ & $17.0 \%$ & $24 \%$ \\
\hline $\mathbf{2 0 1 4}$ & $17.9 \%$ & $5 \%$ \\
\hline $\mathbf{2 0 1 5}$ & $19.8 \%$ & $10 \%$ \\
\hline $\mathbf{2 0 1 6}$ & $20.4 \%$ & $3 \%$ \\
\hline $\mathbf{2 0 1 7}$ & $19.0 \%$ & $-7 \%$ \\
\hline
\end{tabular}

Source: Author Analysis, 2018

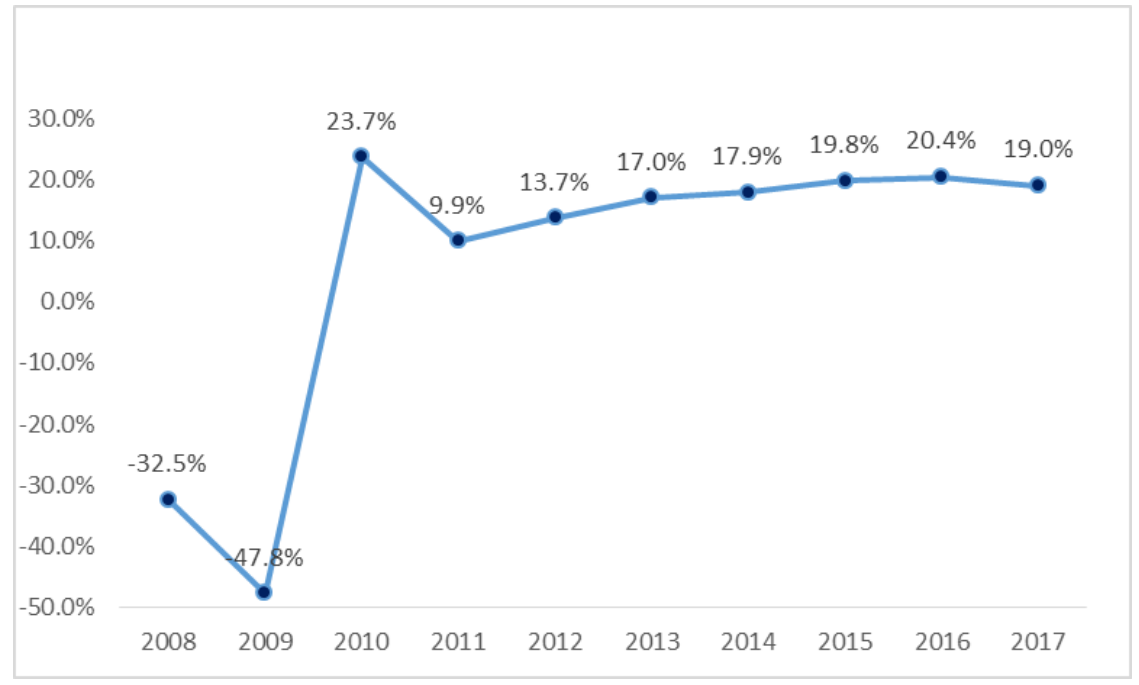

Figure 8. Graph of Profit Margin Calculation (Author Analysis, 2018) 
Based on Table 8 and Figure 8 indicate Profit Margin in year of 2008 to 2017 of PT Matahari Department Store Tbk. Resulting this analysis:

a. Red Period (e-commerce first pilot project)

In 2008, PT. MDS recorded a Profit Margin of $-32.5 \%$. This happened because PT. MDS has a Net Loss or a negative one. Net loss still occurs in 2009 \& in 2010 PT. MDS just got Net Income or was positive from the sale. This increase was due to a company restructuring that increased the sales results of this company.

\section{b. Blue Period (E-Commerce Emergen- ce and Transition)}

In 2011, Profit Margin decreased by 58 . This happened because the bookkeeping of PT. MDS is already independent after the restructuring in 2010 , so there are differences in recording regarding total sales and Net Income from this company.

\section{c. Green period (E-Commerce Boom and Adoption)}

During this period, Profit Margin continued to experience unstable increases but in 2017 it decreased by $7 \%$ compared to the previous year. The decline that occurred in 2011 was due to higher operating expenses in 2017 so that the total net income in 2017 decreased compared to 2016.

\subsubsection{Earnings Per Share (EPS)}

Table 9 and figure 9 below shows the calculation of Earnings Per Share (EPS).

Table 9. Earning Per Share Calculations

\begin{tabular}{|c|c|c|}
\hline Year & Ratio & Growth \\
\hline $\mathbf{2 0 0 8}$ & - Rp14 & 0 \\
\hline $\mathbf{2 0 0 9}$ & - Rp12 & $14 \%$ \\
\hline $\mathbf{2 0 1 0}$ & Rp21 & $275 \%$ \\
\hline $\mathbf{2 0 1 1}$ & Rp160 & $662 \%$ \\
\hline $\mathbf{2 0 1 2}$ & Rp264 & $65 \%$ \\
\hline $\mathbf{2 0 1 3}$ & Rp394 & $49 \%$ \\
\hline $\mathbf{2 0 1 4}$ & Rp486 & $23 \%$ \\
\hline $\mathbf{2 0 1 5}$ & Rp610 & $25 \%$ \\
\hline $\mathbf{2 0 1 6}$ & Rp692 & $13 \%$ \\
\hline $\mathbf{2 0 1 7}$ & Rp654 & $-6 \%$ \\
\hline
\end{tabular}

Source: Author Analysis, 2018 


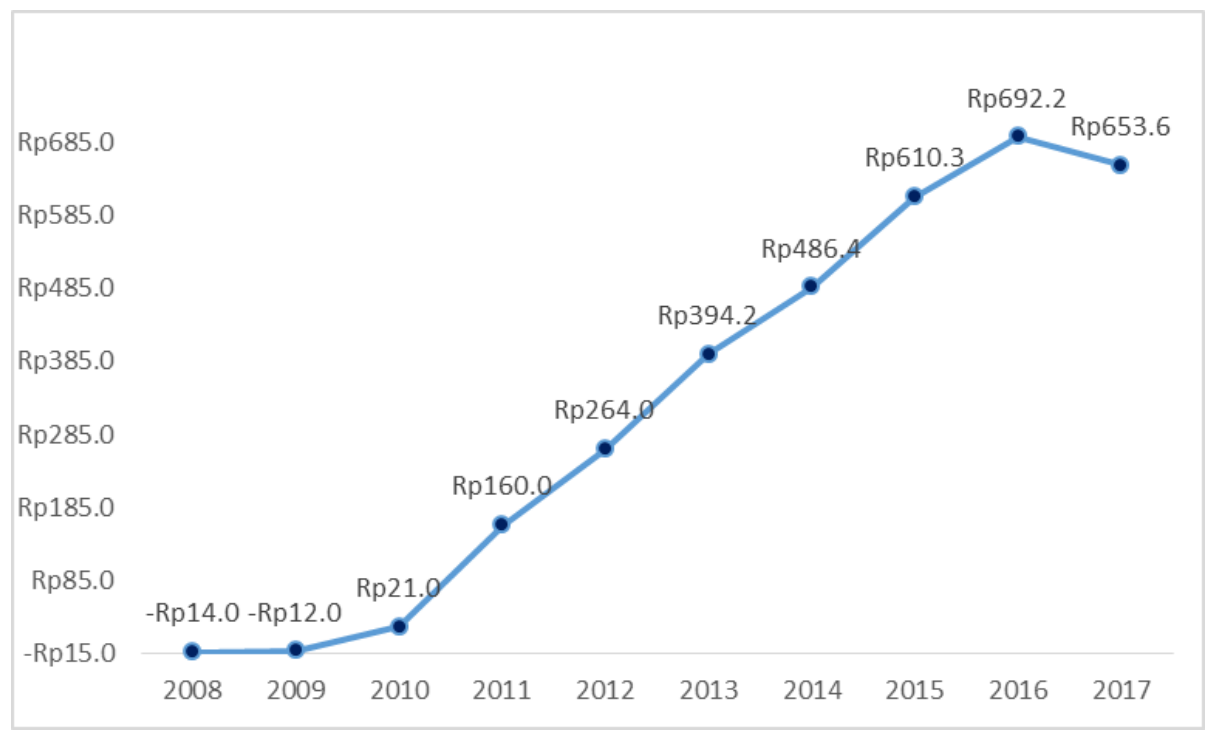

Figure 9. Graph of EPS Calculation

(Author Analysis, 2018)

Based on Table 9 and Figure 9 indicate Profit Margin in year of 2008 to 2017 of PT Matahari Department Store Tbk.

Resulting this analysis:

a. Red Period (e-commerce first pilot project)

During this period, PT. MDS records EPS from this company as negative, so the decision of this company to do a Reverse Stock Split so that it raises a Par Value from this company's stock.

\section{b. Blue Period (E-Commerce Emer-gence and Transition)}

In 2011, EPS continued to increase due to the decision in the previous period, which increased by $662 \%$. In addition, this increase also occurred due to an increase in the number of Net Income that continued to grow compared to previous years.

\section{c. Green Period (E-Commerce Boom and Adoption)}

During this period, EPS from PT. MDS continues to increase every year, but this increase actually decreases every year. This is due to an increase in Net Income which continues to increase each year, but this increase is decreasing every year. In 2017, EPS decreased by $6 \%$ due to a decrease in the Net Income of this company. 


\subsubsection{Cash Realization}

Table 10 and figure 10 below shows the calculation of Cash Realization.

Table 10. Cash Realization Calculations

\begin{tabular}{|c|c|c|}
\hline Year & Ratio & Growth \\
\hline 2008 & $-2.26 X$ & 0 \\
\hline 2009 & $-34.76 X$ & $-1438 \%$ \\
\hline 2010 & $1.71 X$ & $-105 \%$ \\
\hline 2011 & $3.28 X$ & $92 \%$ \\
\hline 2012 & $2.45 X$ & $-25 \%$ \\
\hline 2013 & $1.84 X$ & $-25 \%$ \\
\hline 2014 & $1.57 X$ & $-15 \%$ \\
\hline 2015 & $1.52 X$ & $-3 \%$ \\
\hline 2016 & $1.53 X$ & $1 \%$ \\
\hline 2017 & $1.37 X$ & $-10 \%$ \\
\hline
\end{tabular}

Source: Author Analysis, 2018

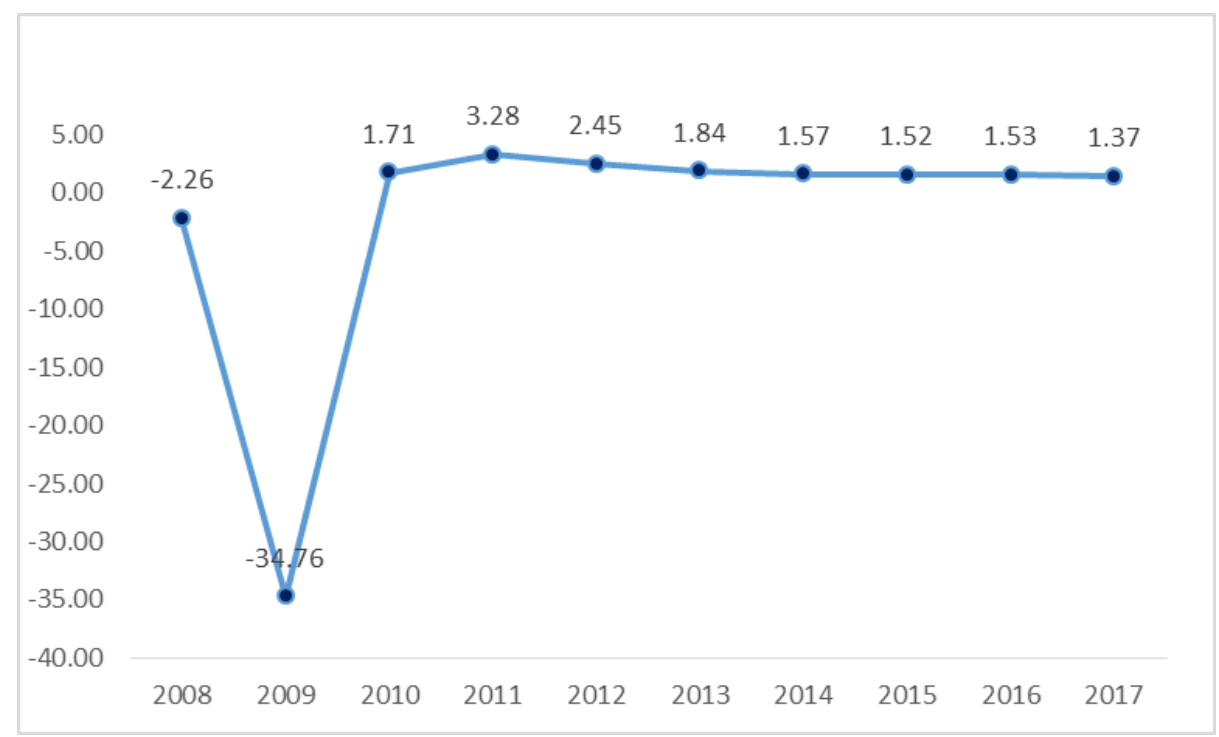

Figure 10. Graph of Cash Realization Calculation (Author Analysis, 2018)

Based on Table 10 and Figure 10 indicate Profit Margin in year of 2008 to 2017 of PT Matahari Department Store Tbk. Resulting this analysis:

a. Red Period (e-commerce first pilot project)
In this period, there was an increase in Cash Generated from Operations of this company and the increase occurred significantly, especially in 2009 compared to 2008. However, on the Net Income this company in that year still did not occur and Net Loss occurred so that the value of 
the company's Cash Cash this is negative. In 2010 the company only received a Net Income so that the company's Revenue Cash could be positive and have increased compared to 2009.

\section{b. Blue Period (E-Commerce Emer-gence and Transition)}

In this period the value of this company's Cash Generated from Operations and Net Income continued to increase, so that Cash Realization also increased compared to the previous period.

\section{c. Green Period (E-Commerce Boom and Adoption)}

During the green period, the Cash Realization of this company has decreased continuously due to the comparison of the increase in Cash Generated from Operations with the Net Income of this company so that the value of Cash Realization will also decrease. In 2017 both of these variables decreased both for Cash Generated Form Operations and also the Net Income of this company so that the value of Cash Realization decreased by 10\% compared to 2016.

\section{Limitation}

This study illustrates the state of performance and profitability of one company engaged in the conventional fashion retail store, namely PT Matahari Department store. This sample were chosen because PT. Matahari Deparment Store is one of the largest, oldest, and have been known for the long time in Indonesia, and also the limitation to access the annual report of the similar company. Analysis and similar studies are needed with more sample companies to describe industry conditions in the aggregate.

This study only uses 2 (overall performance result \& profitability measure) ratio of the 5 parts (performance result, profitability measure, financial test
$\&$ dividend policy) ratio to analyze the financial condition of a company because the two ratios are ratio which better to describes the condition of profitability and company performance. This study only describes the profitability and performance of PT Matahari Department Store Tbk in the period 2008-2017. Other studies are needed to enrich the results of this study in a longer period of time, more samples, addition of other ratio analysis and addition of other variables (nonfinancial variables).

\section{Conclusion and Recommendation}

Overall in this study, produced the following conclusions:

a. Red Period, 2008-2010 (e-commerce first pilot project)

In the 2008-2009 periods, PT MDS recorded a performance that was not good enough, reflected in companies that suffered losses which resulted in the company's financial ratio producing negative values (EPS, ROA, ROI, ROE, Profit Margin, EPS, \& cash realization). Only the Gross Margin percentage has a positive value. In 2009, the company carried out a corporate action namely the stock reverse to improve the company's performance in the financial statements for the 2009-2010 financial year and the following year.

b. Blue Period, 2011 (E-Commerce Emergence and Transition)

In 2011, PT MDS began to improve its financial performance by successfully recording profits this year. This result are positive financial ratios except ROE, this occurs because of the impact of corporate actions namely reverse stock and corporate restructuring.
c. Green Period (E-Commerce Boom and Adoption)

In the 2012-2016 periods, the company 
managed to increase company profits from year to year. This results in the company's positive performance in the financial statements. In this period, precisely in 2013, the company carried out a corporate action whereby PT Asia Color Company Ltd, as the owner of $98.15 \%$ shares, sold $66 \%$ of its shares to the public at $45.7 \%$ and to PT Multipolar Tbk $20.48 \%$. The increase in the number of public offers will drive up the price of PT MDS shares and boost the company's ratio. In 2017, the company still recorded profits, but profit growth was not as big as the previous year.

Based on the above conclusions and referring to the timeline for the emergence of e-commerce pilot projects (2008-2010), emergence \& transition e-commerce (2011), up to the e-commerce boom (2012-2017), the company's performance and profitability were not affected by the emergence of e-commerce. The company actually recorded a negative performance in the period 2008-2010 (before ecommerce emerged) and experienced improvements in company performance precisely during the e-commerce boom (2011-2017). This is caused by:

1. The company's performance was not affected by the emergence of ECommerce, the company's performance and profitability was influenced by corporate actions such as the stock reverse in 2009, an increase in the shareholding of public ownership in 2013, massive corporate restructuring and improvements. Corporate restructuring enables companies to improve financial conditions, organizational structure, corporate policies, and corporate strategies so that the company continues to perform well in the digital era (ecommerce).
2. "Matahari" brand capital owned by PT Matahari Department Store Tbk. very strong in Indonesia. This is because the brand "Matahari" has been known and trusted for a long time by the Indonesian people, PT Matahari Department Store Tbk. has a large number of loyal customers and PT MDS segment customers are different consumer segments from the consumer segment targeted by e-commerce. This has resulted in the sale of PT MDS not being disrupted by the existence of e-commerce.

3. Volatility in the number of sales revenue of PT Matahari Department Store Tbk. influenced by the company's marketing strategy (price, promotion, fashion product) and the level of company services offered by PT MDS to consumers in Indonesia. This is what distinguishes PT MDS from other online stores.

4. PT Matahari Department Store Tbk. continue to improve its performance and be able to adapt well to the digital era. This was marked by the addition of a shopping service launched by PT MDS in 2015 namely MatahariMall.com which later transformed into Matahari.com to facilitate access to PT MDS consumer shopping activities and target other market targets or segments.

5. Improvements in company performance occur because companies make efficiency on various sides. One of them is the company continues to open new outlets in places that have a large potential market. On the other hand, companies also close shopping outlets in places that are not productive or not profitable. 


\section{References}

Anthony, R. N., Hawkins, D.F, \& Merchant, K. (2012). Accounting: Text and Cases. New Delhi: McGrawHill Publishing.

Anthony, R. N., Reece, J.S., \& Hertenstein, J.H. (2011). Accounting: Text and Cases, 13 th Ed. Chicago: Irwin

Asosiasi Penyelenggara Jasa Internet Indonesia [APJII] (2014). Profil Pengguna Internet Indonesia. Jakarta: Asosiasi Penyelenggara Jasa Internet Indonesia

Author Analysis (2018). Earning Per Share Calculations

Author Analysis (2018). Earning Per Share Calculations

Author Analysis (2018). Financial Ratios of Overall Performance 2008-2017

Author Analysis (2018). Financial Ratios of Overall Performance 2008-2017

Author Analysis (2018). Graph of Cash Realization Calculation

Author Analysis (2018). Graph of EPS Calculation

Author Analysis (2018). Graph of Gross Margin Calculation

Author Analysis (2018). Graph of Profit Margin Calculation

Author Analysis (2018). Graph of ROA Calculation

Author Analysis (2018). Graph of RoE Calculation

Author Analysis (2018). Graph of RoIC Calculation

Author Analysis (2018). Gross Margin Calculations

Author Analysis (2018). Price Earning Ratio (PER) and Growth Calculations
Author Analysis (2018). Profit Margin Calculations

Author Analysis (2018). PT MDS Market Price Trend

Author Analysis (2018). ROA Calculations

Author Analysis (2018). RoE Calculations

Author Analysis (2018). RoIC Calculations

Author Analysis (2018). Timeline of growth E-Commerce and PT Matahari Department Store Tbk. in Indonesia.

Ayu, P. E. (2014). Analisis Laporan Keuangan Untuk Menilai Kinerja Keuangan PT. Matahari Department Store, Tbk yang Terdaftar di Bursa Efek Indonesia periode 2012-2014. Jakarta: Gunadarma.

Daryanto, W. M. (2017). Financial performance analysis and evaluation of palm oil agroindustry: an Indonesia experience. Jurnal Ilmiah Manajemen dan Bisnis. 3(1), Maret 2017. ISSN 2460 8424, 108-126.

Daryanto, W. M., Nurfadilah D. (2018). Financial performance analysis before and after the decline in oil production: case study in Indonesia oil and gas industry. International Journal of Engineering \& Technology, 7 (3.21), 10-15.

Daryanto, W. M., Primadona A. (2018). Capital budgeting model and sensitivity analysis of the conventional oil Production Sharing Contract (PSC) fiscal systems: empirical evidence from Indonesia. International Journal of Engineering \& Technology, 7 (3.21), 5-9.

Daryanto, W. M., Samidi S. (2018). Measuring the financial performance of enterprises under Ministry of Energy and Mineral Resources (EMR) an Indonesia experience. International Journal of Enginee- 
ring \& Technology, 7 (3.21), 16-23.

Halkos, G. E., Salamouris, D. S. (2004). Efficiency measurement of the greek commercial bank with the use of financial ratio; a data envelopment analysis approach. Management Accounting Research. 15(2).

Indah R, Monika. (2016). Analisis Kinerja Keuangan PT Mathari Department Store Tbk Berdasarkan Rasio Likuiditas, Solvabilitas, Profitabilitas, dan Aktivitas Pada Tahun 20102014. Surakarta: Universitas Sebelas Maret.

Kotler, Philip. (2000). Marketing Management, Milenium Edition. New Jersey: Prentice Hall Intl, Inc.

Kumbirai, M., Webb, R. (2010). A financial ratio analysis of commercial bank performance in South Africa. African Review of Economics and Finance 2(1), 3053.

Megaladevi, P. (2015). A study on financial performance analysis of the selected paper company with special reference to Tamil Nadu Newsprint and Papers Limited. International Journal of Recent Research Aspects, 2(4), 22-24.

PT. Matahari Department Store Tbk. (2009). 2008 annual report of the PT. Matahari Department Store Tbk.

PT. Matahari Department Store Tbk. (2010). 2009 annual report of the PT. Matahari Department Store Tbk.

PT. Matahari Department Store Tbk. (2011). 2010 annual report of the PT. Matahari Department Store Tbk.

PT. Matahari Department Store Tbk. (2012). 2011 annual report of the PT. Matahari Department Store
Tbk.

PT. Matahari Department Store Tbk. (2013). 2012 annual report of the PT. Matahari Department Store Tbk.

PT. Matahari Department Store Tbk. (2014). 2013 annual report of the PT. Matahari Department Store Tbk.

PT. Matahari Department Store Tbk. (2015). 2014 annual report of the PT. Matahari Department Store Tbk.

PT. Matahari Department Store Tbk. (2016). 2015 annual report of the PT. Matahari Department Store Tbk.

PT. Matahari Department Store Tbk. (2017). 2016 annual report of the PT. Matahari Department Store Tbk.

PT. Matahari Department Store Tbk. (2018). 2017 annual report of the PT. Matahari Department Store Tbk.

Statisa Research. (2018). Digitalization, Done in 60 Seconds. Statista Research

Tarawneh M (2004). A comparison of financial performance in the banking sector: some evidence from Omani Commercial Banks. International Research Journal of Finance and Economics. 3(3). 